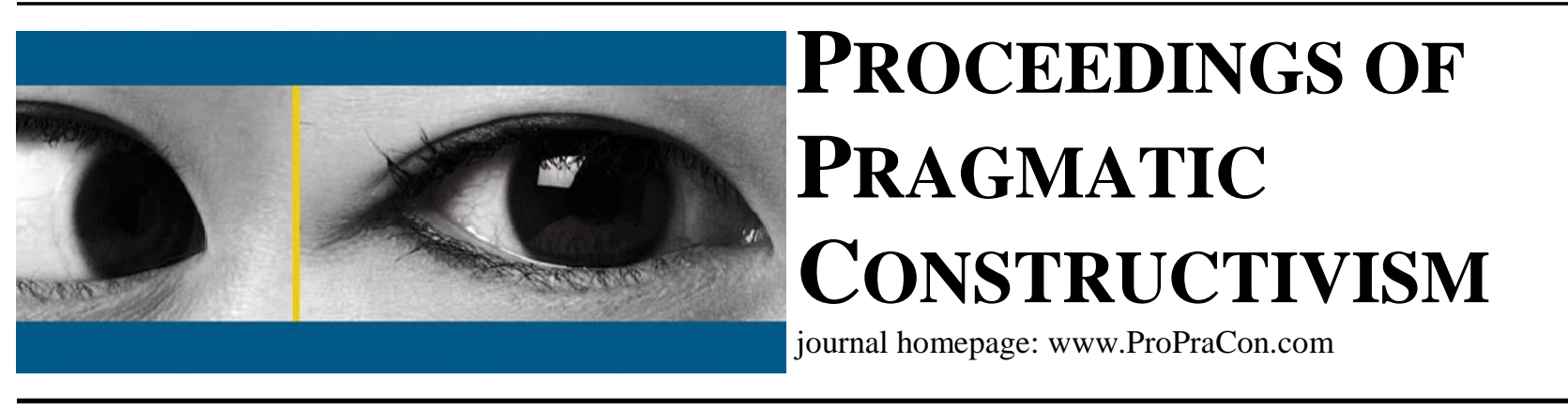

\title{
Pragmatic Constructivism and Inter-Organisational Decision Making
}

\author{
Dr. Pinar Guven Uslu \\ Norwich Business School, University of East Anglia, England, UK \\ E-mail: P.Guven@uea.ac.uk \\ Dr. Zlatinka Blaber \\ Bertolon School of Business, Salem State University, USA \\ E-mail: zlatinka.blaber@salemstate.edu
}

\author{
Dr Pawan Adhikari \\ Essex Business School, University of Essex, UK. \\ E-mail: padhik@essex.ac.uk
}

This paper is about the use of management accounting information for inter organizational decision making. We propose that the framework outlined by Nørreklit et al. (2017) is suitable for the study of this topic and to contribute to inter organisational decision making literature.

There is a need for developing inter-organisational decision-making models (Dekker, 2016) and making such models match the complexities of practical reality (Nørreklit et al, 2017). This reality involves a high degree of information uncertainty and a coalition of decision participants. Drawing on Pragmatic Paradigm (Nørreklit et al 2006, 2007; Nørreklit 2011; Nørreklit, 2017) Nørreklit et al (2017) outline a framework for the study of organisational decision making by employing the case study research method. These authors use the conceptual fundamentals of Pragmatic Constructivism whose main components of reality construction are:

Actorship and authorship

Four dimensions of reality (facts, possibilities, values and communication)

Constructing causality to integrate the four dimensions above

Integrative learning theory of truth - knowledge about reality construction

The paper focuses on one component of the framework that is 'actorship and authorship' and discusses the interrelationships between that and the other components of reality in the decision making process studied. Pragmatic constructivist framework provided an appropriate tool to study the role of boundary spanners as the main actors of inter organizational decision making.

The data is collected through interviews, observation of meetings and documentary analysis. The boundary spanners BSs in this research are chosen from the commissioning field of the English National Health Service (the NHS). Nineteen BSs from 12 organisations were interviewed. BSs had varied professional backgrounds; clinicians, managers and accountants employed in either health provider organisations such as hospitals and local general practice clinics or commissioning organisations. In addition to interviews, researchers observed four commissioning meetings in two different settings. These notes were supplemented by notes taken at two national commissioning conferences and one acute care conference which had a commissioning track. Analysis of policy documents of the government provided the third source of data. The data were analysed with the MAXQDA10 software. 
The main findings of the study are as follows: joint authorship between BSs is an essential component of IODM. The case study evidence indicated that joint authorship was largely neglected in health care commissioning. A lack of joint authorship seemed to have affected significantly the inter-organisational relationships, as well as the differences in and a lack of consistency in control practices. The study of facts, values, possibilities and communication revealed that inconsistent financial and managerial practices led to tensions and confrontations among partner organisations and had a limiting effect on IODM. Limitations of these facts drove the BSs to generate new possibilities and find practical solutions for commissioning decisions. Communications among partners were kept confidential and this affected the trust among them. As a consequence, in each decision-making scenario a different practical solution was devised with the help of different sets of data. The use of the PC framework proved to be an appropriate tool to show that confidential communications with partner organisations was causing problems in IODM. Finally, in spite of the fact that BSs turned out to be accepting of the basic theoretical precepts of the learning theory of truth, they did not make use of this to learn from their experience. Using the PC framework helped show that the learning theory of truth was an essential element of IODM and that BSs could learn from past experience.

\section{References}

Dekker, H.C. (2016) 'On the boundaries between intra form and inter firm management accounting research', Management Accounting Research, 31, 86-99.

Nørreklit, H., Nørreklit, L. and Mitchell, F. (2010), ‘Towards a paradigmatic foundation for accounting practice’ , Accounting, Auditing \& Accountability Journal, Vol. 23 No. 6, pp. 733-758.

Nørreklit, H., Nørreklit, L., Mitchell, F. and Bjørnenak, T. (2012), 'The rise of the balanced scorecard! Relevance regained?’ Journal of Accounting \& Organizational Change, Vol. 8 No. 4, pp. 490-510.

Nørreklit, L. (2011), 'Actors and reality: a conceptual framework for creative governance', in Jakobsen, M., Johansson, I. and Nørreklit, H. (Eds), An Actor's Approach to Management, Djof Publishing, Copenhagen, pp. 7-38

Nørreklit, H. (2017) A Philosophy of Management Accounting: A pragmatic constructivist approach (eds) Routledge: New York.

Nørreklit, H.; Mitchell, F and Nielsen L B (2017a) 'Reflective planning and decision making' in A Philosophy of Management Accounting: A Pragmatic Constructivist Approach, edited by Hanne Nørreklit, Chapter 4, Routledge: New York.

Nørreklit, H.; Mitchell, F and Raffnsoe-Moller, M (2017b) 'Introduction' in A Philosophy of Management Accounting: A Pragmatic Constructivist Approach, edited by Hanne Nørreklit, Chapter 1, Routledge: New York.

Nørreklit, L. (2017) ‘Actor reality construction’ in A Philosophy of Management Accounting: A Pragmatic Constructivist Approach, edited by Hanne Nørreklit, Chapter 2, Routledge: New York. 